\title{
Electrochemical study of selenium (IV) mediated by carbon nanotubes modified glassy carbon electrode in blood medium
}

Muhammed Mizher RADHI - Health and Medical Technology College-Baghdad,

Middle Technical University (MTU), Iraq • mmradhi@yahoo.com

Wasan A. Gharbi AL-DULIMY - College of Veterinary Medicine, University of Baghdad, Iraq

- dr.wasangharby@yahoo.com

MaYSARA SAmER KHALAF - Health and Medical Technology College-Baghdad,

Middle Technical University (MTU), Iraq

Érkezett: 2016. 06. 13. - Received: 13. 06. 2016. - http://dx.doi.org/10.14382/epitoanyag-jsbcm.2016.16

\section{Abstract}

Sodium selenite Se(IV) was studied by cyclic voltammetric technique to identify the extent of its effect on both normal saline and blood medium components as oxidative or antioxidative reagent. Carbon nanotube (CNT) was used to modify glassy carbon electrode (GCE) for the enhancement of redox current peaks. It was found from the results of the study that reduction current peak of $\mathrm{Se}(\mathrm{IV})$ in blood medium appears at $-1 \mathrm{~V}$ in $0.1 \mathrm{mM}$ of sodium selenite, but the reduction current peak disappears when adding more amount of Se(IV) to the blood which causes enhancement of the oxidation current peak of $\mathrm{Se}(\mathrm{IV})$ at $0.25 \mathrm{~V}$ in $10 \mathrm{mM}$ of sodium selenite. Ascorbic acid (AA) was affected on the redox current peaks of Se(IV) in blood medium that enhanced the cathodic current peak and disappearing the anodic current peak. So sodium selenite considered as antioxidative material at low concentration in blood medium and become oxidative in high concentration especially in presence of AA.

Keywords: cyclic voltammetry, carbon nanotube, glassy carbon electrode, blood medium, sodium selenite, normal saline

\section{Introduction}

Scientists used a new method of electrochemical analysis using cyclic voltammetric technique for infected blood pollution which cause of many diseases by blood complexation of the component act as poisoning [1-7].

Selenium (IV) ions in the compound of sodium selenite $\left(\mathrm{Na}_{2} \mathrm{SeO}_{3}\right)$ were shown in scheme (1). Most of selenium salts are toxic in high concentrations and the chronic toxicity dose for human beings is about 2.4 to 3.0 milligrams of selenium per day $[8,9]$.

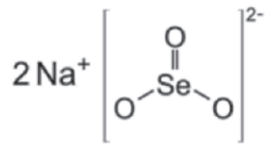

Cyclic voltammetric technique was used for the determination of the selenium electrodeposition onto GCE in sulphuric acid medium. Thin layer of Se on the GCE modified working electrode comparing with GCE bar for determination of some electrochemical parameters such as charge transfer rate values with good results at modified GCE which selenium act as electro catalyst [10].

Cathodic stripping voltammetry was used for the determination of selenium in natural waters in present of rhodium. A high detection limit of 2.4pM Se(IV) was found in this technique [11].

Square wave anodic stripping voltammetric technique was used for the determination of selenium(IV) by microfabrication array of gold ultramicroelectrodes which show a good rapid, sensitive and reproducible response for selenium ions [12].

A new mechanism of selenium electrodeposition from $\mathrm{H}_{2} \mathrm{SO}_{4}$ solution on different substrates such as gold, silver and copper electrodes was studied for reduction current peaks of selenous acid and confirms the mechanism of the deposition process [13].

Cyclic voltammetry and differential pulse voltammetry were used for the electrochemical characterization of azulene selenium compound [14].

$\mathrm{Se}(\mathrm{IV})$ ions in acid medium was studied by dropping mercury electrode technique to observe three voltammetric reduction current peaks of $\mathrm{H}_{2} \mathrm{SeO}_{3}, \mathrm{HgSe}$ and $\mathrm{H}_{2} \mathrm{Se}$ which studied the behavior of $\mathrm{Se}(\mathrm{IV})$ on cyclic scanning [15].

The reversible of oxidation-reduction process of Se(IV)/ (VI) was determined by cyclic voltammetric technique by the following reaction [16]:

$\mathrm{SeO}_{4}^{2-}+2 \mathrm{H}^{+}+2 \mathrm{e}^{--}=\mathrm{SeO}_{3}^{2-}+\mathrm{H}_{2} \mathrm{O}$

Cyclic voltammetry and cathodic linear stripping voltammetry were used for the determination of selenium deposition by sulfate solution on gold electrode. The results found $\mathrm{Se}(0) /(2-)$ reduction current peak which are related to the surface limited phenomena of selenium process [17].

The $\mathrm{Se}(\mathrm{VI}) /(\mathrm{IV})$ reaction was investigated by cyclic voltammetry to find the oxidation-reduction potential as in the following reaction [18]: 


$$
\begin{aligned}
& \mathrm{SeO}_{4}^{2-}+2 \mathrm{H}^{+}+2 \mathrm{e}^{-} \rightleftharpoons \mathrm{SeO}_{3}^{2-}+\mathrm{H}_{2} \mathrm{O} \\
& E^{0}\left(\mathrm{SeO}_{4}^{2-} / \mathrm{SeO}_{3}^{2-}\right)=0.8227 \pm 0.0032 \mathrm{~V} \\
& \varepsilon\left(\mathrm{SeO}_{4}^{2-}, \mathrm{Na}^{+}\right)-\varepsilon\left(\mathrm{SeO}_{3}^{2-}, \mathrm{Na}^{+}\right)=0.59 \pm 0.12 \mathrm{~kg} \mathrm{~mole}^{-1}
\end{aligned}
$$

Selenium nanoparticles were deposited on working electrode using cyclic voltammetric technique to study specific capacitance of $21.98 \mathrm{Fg}^{-1}$ with $91 \%$ electrochemical stability [19].

Selenium was electrodeposited on gold substrates by $\mathrm{HNO}_{3}$ solution using cyclic voltammetric technique. It was found that the reduction of $\mathrm{Se}^{2+}$ to $\mathrm{Se}^{0}$ occurs by electron mechanism at more negative potential [20].

The potential of $\mathrm{Se}(\mathrm{VI} / \mathrm{IV})$ was studied in high $\mathrm{pH}$ by cyclic voltammetric technique, and the results found that $\mathrm{E}^{0}\left(\mathrm{SeO}_{4}^{2-}\right.$ $\left.\mathrm{SeO}_{3}{ }^{2-}\right)=0.8227 \pm 0.0032 \mathrm{~V}, \Delta \varepsilon=0.59 \pm 0.12 \mathrm{~kg} / \mathrm{mol}[21]$.

In this work sodium selenite in different electrolytes including blood medium was studied by cyclic voltammetric technique using GCE modified with CNT for the determination of electrochemical properties of Se(IV) in blood medium.

\section{Experimental}

\subsection{Reagents and chemicals}

Sodium selenite from Thomas Baker (India), normal saline $(0.9 \% \mathrm{NaCl} \mathrm{W} / \mathrm{V})$ from Alcon Parenterals (India) Ltd, ascorbic acid (AA) from Technicon chemicals Co. (Oreq Tournai Belgique), healthy human blood samples was received from Iraqi blood bank in Baghdad city of medicine, and other chemicals and solvents were of annular grade and used as received from the manufacturer. Deionized distilled water was used for the preparation of aqueous solutions.

\subsection{Preparation of modified glassy carbon electrode}

Glassy carbon working electrode modified with carbon nanotube using attachment method to become CNT/GCE was used in this work after cleaning by polishing the surface of GCE with alumina powder and deionized distilled water $[22,23]$.

\subsection{Apparatus and procedures}

Instruments: EZstat series (potentiostat/galvanostat) NuVant Systems Inc. pioneering electrochemical technologies USA. Electrochemical workstations of Bioanalytical system with potentiostat driven by electroanalytical measuring software was connected to personal computer to perform Cyclic Voltammetry (CV). $\mathrm{Ag} / \mathrm{AgCl}(3 \mathrm{M} \mathrm{NaCl})$ and platinum wire (1 $\mathrm{mm}$ diameter) was used as a reference and counter electrode, respectively. The glassy carbon working electrode (GCE) was used in this study after cleaning with alumina powder.

Procedure: cyclic voltammetric cell was used in this technique by adding $10 \mathrm{ml}$ of electrolyte (human blood samples) in the quartz cell and immerse three electrodes in the blood medium (GCE as working electrode or GCE modified with CNT, Ag/ $\mathrm{AgCl}$ reference electrode and counter electrode), then the electrodes was connected with potentiostat to find the results by the cyclic voltammogram using a personal computer.

\section{Results and discussion}

\subsection{Enhancement study}

Fig. 1 shows the cyclic voltammogram of Se(IV) in normal saline with different electrodes. It was found that glassy carbon electrode modified with carbon nanotube enhanced the oxidation current peak of $\mathrm{Se}(\mathrm{IV})$ about two times which act as electro-catalyst in the different electrolytes. It is very important to use nano-sensors like CNT/GCE in this study for the determination of low detection limit selenium compounds in blood medium which can determine the accuracy of the $\mathrm{Se}(\mathrm{IV})$ concentration in the electrolytes.

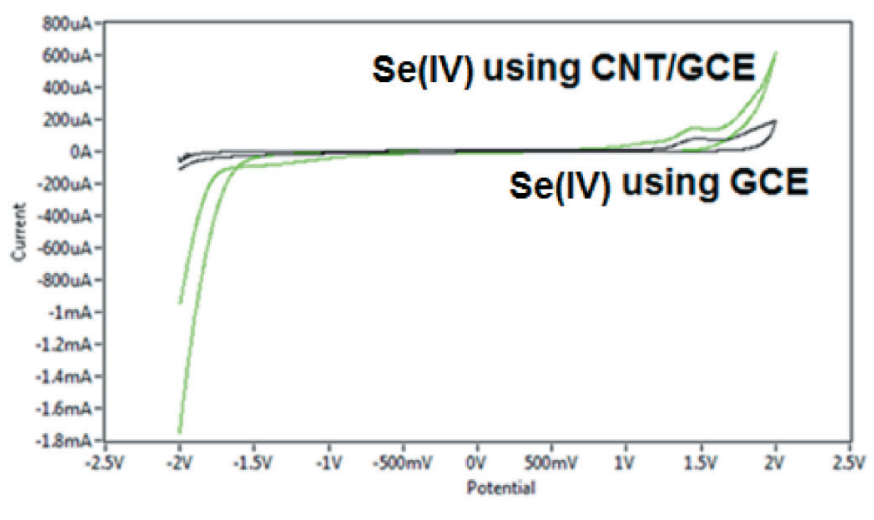

Fig. 1. Cyclic voltammogram of Se(II) in normal saline at GCE and CNT/GCE as working electrodes and $\mathrm{Ag} / \mathrm{AgCl}$ as reference electrode, scan rate $100 \mathrm{mVsec}^{-1}$.

1. ábra Se(II) ciklikus voltammogramja normál nyálban; mérő elektródák: GCE és CNT/GCE, referencia elektróda: $\mathrm{Ag} / \mathrm{AgCl}$, adatrögzítési sebesség: $100 \mathrm{mVsec}{ }^{-1}$.

\subsection{Effect of Se(IV) on blood medium}

In previous studies conducted by researchers, the effect of sodium selenite on the blood of animals in terms of RBC account and the poisoning due to exposure to doses of selenium salts were studied $[24,25]$. In the current study, a new method was used to determine the effect of sodium selenite in blood medium using electrochemical method to detect the effect of different concentrations through the oxidation-reduction current peaks in blood medium. Fig. 2 shows the effect of low concentration of $0.1 \mathrm{mM} \mathrm{Se}(\mathrm{IV})$ in blood medium by appearing of reduction peak at $-1 \mathrm{~V}$, and high concentration of $10 \mathrm{mM}$ Se(IV) which finding a new phenomenon by disappearing of the reduction peak and appearing the oxidation current peak at $0.25 \mathrm{~V}$. This means that low concentration of selenium ions act as antioxidant in blood medium and the high concentration of selenium ions causes oxidation of the blood components as illustrated in the following equation:

$\mathrm{SeO}_{3}^{4-}+2 \mathrm{e}=\mathrm{SeO}_{3}^{2-} \quad \mathrm{E}=0.25 \mathrm{~V}$

From Table 1 it was found that the effect of low concentrations of sodium selenite in blood medium act as antioxidant reagent, but when increasing the concentration of selenite from $1.6 \mathrm{mM}$ and above the reduction current peak disappears and enhances the oxidation current peaks. 


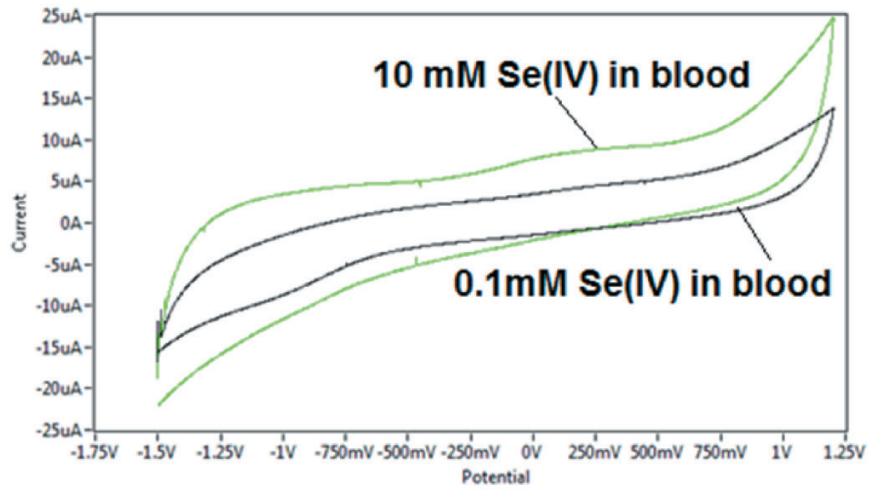

Fig. 2. Cyclic voltammogram of $0.1 \mathrm{mM} \mathrm{Se}(I V)$ and $10 \mathrm{mM} \mathrm{Se}(I V)$ in blood medium at CNT/GCE as modified electrode and $\mathrm{Ag} / \mathrm{AgCl}$ as reference electrode, at scan rate $100 \mathrm{mVsec}^{-1}$.

2. ábra $0.1 \mathrm{mMSe}(\mathrm{IV})$ és $10 \mathrm{mM} \mathrm{Se}(\mathrm{IV})$ ciklikus voltammogramja vér közegben; mérö elektróda: $C N T / G C E$, referencia elektróda: $\mathrm{Ag} / \mathrm{AgCl}$, adatrögzítési sebesség: $100 \mathrm{mVsec}^{-1}$.

\subsection{Effect ascorbic acid on Se(IV) in blood medium}

The results of previous researches after using the treatment of $\mathrm{N}$-acetyle L-cystine is a substitute for glutathione due to selenium toxicity $[26,27]$.

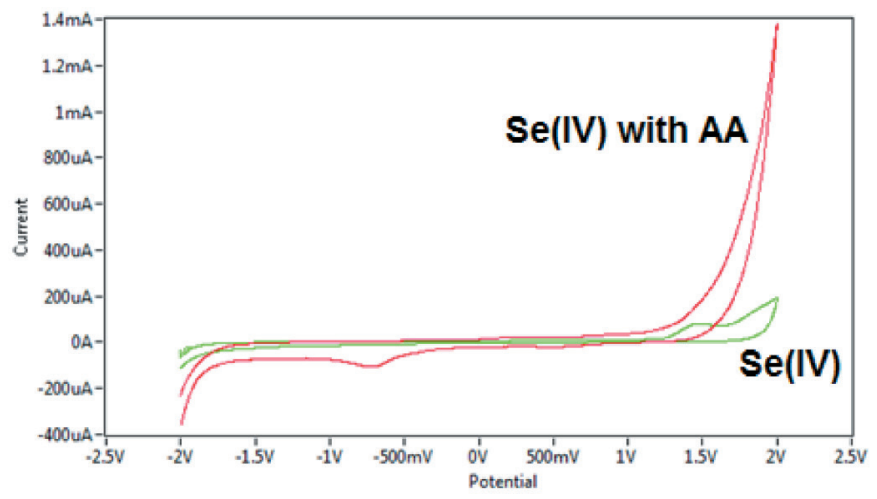

Fig. 3. Cyclic voltammogram of $0.3 \mathrm{mM} S$ Se(II) with $A A$ and without $A A$ in normal saline at CNT/GCE as modified electrode and $\mathrm{Ag} / \mathrm{AgCl}$ as reference electrode, at scan rate $100 \mathrm{mVsec}^{-1}$

3. ábra $0.3 \mathrm{mM} \mathrm{Se(II)} \mathrm{ciklikus} \mathrm{voltammogramja} \mathrm{normál} \mathrm{nyálban,} \mathrm{aszkorbinsav}$ jelenlétében és anélkül; mérö elektróda: $C N T / G C E$, referencia elektróda: $\mathrm{Ag} / \mathrm{AgCl}$, adatrögzitési sebesség: $100 \mathrm{mVsec}^{-1}$.

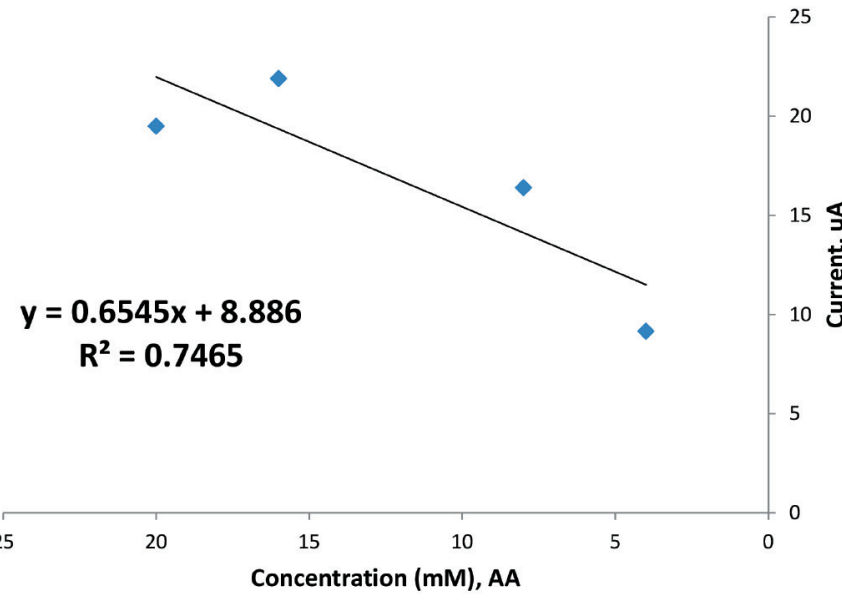

Fig. 4. Plot of the cathodic current peaks against the different concentrations of $A A$ with $40 \mathrm{mM}$ of sodium selenite in blood medium.

4. ábra Katódos áramerősség csúcsértékek $40 \mathrm{mM}$ nátrium-szelenitre vonatkozóan vér közegben, az aszkorbinsav koncentráció függvényében ábrázolva.
It was found in this study that it is good treatment to prevent the oxidative stress of $\mathrm{Se}(\mathrm{IV})$ in blood medium by using ascorbic acid (AA) as antioxidative reagent for Se(IV) in blood medium as shown in Fig. 3. Results illustrate that oxidation current peak of $\mathrm{Se}(\mathrm{IV})$ appears at $1.5 \mathrm{~V}$ in the absence of $\mathrm{AA}$, but it can be clearly seen that the oxidation current peak of $\mathrm{Se}(\mathrm{IV})$ disappears when using AA and enhances the reduction current peak of $\mathrm{Se}(\mathrm{IV})$ at $-0.75 \mathrm{~V}$. This means that AA acts as antioxidative reagent for $\mathrm{Se}(\mathrm{IV})$ in blood medium. Table 1 indicates the relationship between the oxidation current peaks of sodium selenite with different concentrations of AA in blood medium. The oxidative stress appears for Se(IV) on the blood component especially in the presence of AA as shown in Fig. 4. It means that AA acts as electrochemical catalyst for $\mathrm{Se}(\mathrm{IV})$ in blood medium and enhances the oxidation effect of selenite in blood medium.

\begin{tabular}{rcccc}
$\mathrm{Na}_{2} \mathrm{SeO}_{3}$, & Ipa, uA & Epa, V & Ipc, uA & Epc V \\
$\mathbf{~ m M}$ & - & - & 8.86 & -1 \\
\hline 0.8 & - & - & 8.69 & -0.985 \\
\hline 1.2 & - & - & 8.48 & -0.848 \\
\hline 1.6 & 3.97 & 0.123 & - & - \\
\hline 2 & 3.92 & 0.192 & - & - \\
\hline 2.4 & 3.78 & 0.152 & - & - \\
\hline 2.8 & 3.97 & 0.46 & - & - \\
\hline 3.2 & 3.97 & 0.146 & - & - \\
\hline 3.6 & 4.11 & 0.15 & - & - \\
\hline 4 & 4 & 0.115 & - & - \\
\hline 8 & 8.74 & 0.186 & - & - \\
\hline 12 & 5.77 & 0.018 & - & - \\
\hline 16 & 5.77 & 0.014 & - & - \\
\hline 20 & 5.77 & 0.073 & - & - \\
\hline 24 & 5.68 & 0.056 & - & - \\
\hline 28 & 5.52 & 0.063 & - & - \\
\hline 32 & 5.59 & 0.074 & - & - \\
\hline 36 & 5.59 & 0.074 & - & - \\
\hline 40 & 5.59 & 0.027 & - & - \\
\hline 44 & 5.94 & 0.02 & - & - \\
\hline
\end{tabular}

\begin{tabular}{ccccc}
$\mathbf{A A}, \mathbf{m M}$ & & & & \\
4 & - & - & 9.16 & 0.033 \\
\hline 8 & - & - & 16.40 & 0.198 \\
\hline 12 & - & - & - & - \\
\hline 16 & - & - & 21.90 & 0.063 \\
\hline 20 & - & - & 19.50 & 0.054
\end{tabular}

\footnotetext{
Table 1 Oxidation-reduction current peaks and potentials of sodium selenite in blood medium, and with $A A$.

1. táblázat Oxidáció-redukció áramerösség csúcsértékek és potenciálkülönbségek nátrium-szelenitre vonatkozóan vér közegben, aszkorbinsav jelenlétében.
}

\section{Conclusions}

Sodium selenite was studied by voltammetric technique. It can be concluded that it is toxic in blood medium as oxidizing reagent at high concentrations and can be considered as antioxidant at low concentrations. Also, it was found that ascorbic acid solution acts as antioxidizing reagent for Se(IV) in blood medium which causes enhancement of reduction current peak of $\mathrm{Se}(\mathrm{IV})$ and causes the oxidation current 
peak to disappear in blood medium, so traces of selenium compounds is very important for human body especially in blood components.

\section{References}

[1] Radhi, M. M. - Tan, W. T. - Ab Rahman, M. Z. B. - Kassim, A. B. (2010): Voltammetric Detection of Mn(II) in Blood Sample at C60 and MWCNT Modified Glassy Carbon Electrodes. American Journal of Applied Sciences, Vol. 7, No. 3, pp. 439-445. http://dx.doi.org/10.3844/ajassp.2010.395.401

[2] Radhi, M. M. - Dawood, D. S. - Al-Damlooji, N. K. - Tee, T. W. (2012): Development of Electrochemical Sensors for the Detection of Mercury by $\mathrm{CNT} / \mathrm{Li}+, \mathrm{C} 60 / \mathrm{Li}+$ and Activated Carbon Modified Glassy Carbon Electrode in Blood Medium. Sensors \& Transducers Journal, Vol. 146, No. 11, pp. 191-202.

[3] Radhi, M. M. - Al-Damlooji, N. K. - Abed, B. K. - Dawood, D. S. - Tee, T. W. (2013): Electrochemical Sensors for Detecting Mn(II) in Blood Medium. Sensors \& Transducers Journal, Vol. 149, No. 2, pp. 89-93.

[4] Radhi, M. M. - Al-Damlooji, N. K. - Jobayr, M. R. - Dawood, D. S. (2013): Electrochemical Sensors of Cyclic Voltammetry to Detect Cd(II) in Blood Medium. Sensors \& Transducers Journal, Vol. 155, No. 8, pp. 150-154.

[5] Radhi, M. M. - Abdullah, H. N. - Al-Asadi, S. A. - Al-Mulla, E. A. J. (2015): Electrochemical oxidation effect of ascorbic acid on mercury ions in blood sample using cyclic voltammetry, International Journal of Industrial Chemistry, Vol. 6, No. 4, pp. 311-316. http://dx.doi.org/10.1007/s40090-015-0053-9

[6] Radhi, M. M. - Albakry, A. A. A. - Jassim, A. M. - Alassady, S. A. - AlMulla, E. A. J. (2016): Electrochemical Study of Pb(II) in Present of Each Ascorbic Acid, Glucose, Urea and Uric Acid Using Blood Medium as an Electrolyte. Nano Biomedicine and Engineering, Vol. 8, No. 1, pp. 9-15. http://dx.doi.org/10.5101/nbe.v8i1.p9-15

[7] Radhi, M. M. - Khalaf, M. S. - Ali, Z. O. - Omran, R. I. (2016): Voltammetric Analysis of Zn (II) in Present of Each Ascorbic Acid (AA) and Folic Acid (FA) in Human Blood Samples. AASCIT Communications, Vol. 3, No. 1, pp. 11-16.

[8] Schrauzer, G. N. (2001): Nutritional selenium supplements: product types, quality, and safety. Journal of the American College of Nutrition, Vol. 20, No. 1, pp. 1-4. http://dx.doi.org/10.1080/07315724.2001.10719007

[9] Wilber, C. G. (1980): Toxicology of selenium. Clinical Toxicology, Vol. 17, No. 2, pp. 171-230. http://dx.doi.org/10.3109/15563658008985076

[10] Simkunaite, D. - Valsiunas, I. (2011): Initial stages of selenium electrodeposition onto glassy carbon electrode. Chemija. Vol. 22, No. 2, pp. 91-97. http://www.lmaleidykla.lt/publ/0235-7216/2011/2/91-97.pdf

[11] Lange, B. - Berg, M. G. (2000): Determination of selenium by catalytic cathodic stripping voltammetry, Analytica Chimica Acta, Vol. 418, pp. 33-42. http://dx.doi.org/10.1016/S0003-2670(00)00940-5

[12] Tan, S. H. - Kounaves, S. P. (1998): Determination of Selenium(IV) at a Microfabricated Gold Ultramicroelectrode Array Using Square Wave Anodic Stripping Voltammetry. Electroanalysis, Vol. 10, No. 6, pp. 364-368. http://dx.doi.org/10.1002/(SICI)1521-4109(199805)10:6<364::AID-ELAN364>3.0.CO;2-F

[13] Kowalik, R. (2014): Microgravimetric studies of selenium electrodeposition onto different substrates. Archives of metallurgy and materials, Vol. 59, No. 3, pp. 871-877. http://dx.doi.org/10.2478/amm-2014-0147

[14] Inel, G. - Soare, M. L. - Bujduveanu, M. R. - Varga, S. E. - Ungureanu, M. - Birzan, L. (2014): Electrochemical characterization of some azulene selenium compounds, U.P.B. Sci. Bull., Series B, Vol. 76, No. 1, pp. 3-10.

[15] Christian, G. D. - Buffle, J. - Haerdi, W. (1980): Study of selenium(IV) at a dropping mercury electrode by cyclic voltammetry with triangle polarization. Journal of Electroanalytical Chemistry and Interfacial Electrochemistry, Vol. 109, No. 1-3, pp. 187-194. http://dx.doi.org/10.1016/S0022-0728(80)80117-3

[16] Doi, R. (2014): Determination of the selenium (VI)/(IV) standard redox potential by cyclic voltammetry. Journal of Nuclear Science and Technology, Vol. 51, No. 1, pp. http://dx.doi.org/10.1080/00223131.2014.847809

[17] Kowalik, R. (2015): The Voltammetric Analysis of Selenium Electrodeposition from $\mathrm{H}_{2} \mathrm{SeO}_{3}$ Solution on Gold Electrode. Archives of Metallurgy and Materials. Vol. 60, No. 1, pp. 57-63. http://dx.doi.org/10.1515/amm-2015-0009
[18] Hassan, H. H. A. - Emad J. A. - Hana’a, A. A. (2016): Enhancement of properties and biodegradability of polybutylene succinate by epoxidized palm oil, Épitöanyag-Journal of Silicate Based and Composite Materials, Vol. 68, No. 1, pp. 2-5. http://dx.doi.org/10.14382/epitoanyag-jsbcm.2016.1

[19] Patil, A. M. - Kumbhar, V. S. - Chodankar, N. R. - Lokhande, A. C. - Lokhande, C. D. (2016): Electrochemical behavior of chemically synthesized selenium thin film. Journal of Colloid and Interface Science, Vol. 469, pp. 257-62. http://dx.doi.org/10.1016/j.jcis.2016.02.030

[20] Bu, L. X. - Wang, W. (2007): Studies on the electrodeposition behavior of selenium by electrochemical impedance spectroscopy and cyclic voltammetry. Thermoelectrics, pp. 413-416.

http://dx.doi.org/10.1109/ICT.2007.4569508

[21] Viswanathan, S. S. - Lee, C. W. (2013): Selenium electrochemistry. RSC Advances, Vol. 3, pp. 10058-10077. http://dx.doi.org/10.1039/C3RA40678D

[22] Tan, W. - Goh, J. (2008): Electrochemical Oxidation of Methionine Mediated by a Fullerene-C60 Modified Gold Electrode. Electroanalysis, Vol. 20, No. 22, pp. 2447-2453. http://dx.doi.org/10.1002/elan.200704335

[23] Jacob, S. - Hong, Q. - Coles, B. - Compton, R. (1999): VariableTemperature Microelectrode Voltammetry: Application to Diffusion Coefficients and Electrode Reaction Mechanisms. The Journal of Physical Chemistry B, Vol. 103, No. 15, pp. 2963-2969. http://dx.doi.org/10.1021/jp990024w

[24] Weiss, W. P. (2003): Selenium nutrition of dairy cows: Comparing responses to organic and inorganic selenium form. Proceeding of the 19th Alltech Annual Symposium Nutrition, Biotechnology Feed Food: 20-23 April 2003; Lexington. Nottingham University Press, Nottingham, UK, pp. 333-373.

[25] Richardson, S. M. - Siciliano, P. D. - Engle, T. E. - Larson, C. K. - Ward, T. L. (2006): Effect of selenium supplementation and source on the selenium status of horses. Journal of Animal Science, Vol. 84, pp. 1742-1748. http://dx.doi.org/10.2527/jas.2005-413

[26] Roder, J. D. (2001): Veterinary toxicology. Butterworth Heinemann. Boston Oxford Auckland. Johannesburg Melbourne, New Delhi. Printed in USA.

[27] Post, L. O. - Keller, W. C. (1999): An update of antidote availability in veterinary medicine. Veterinary and human toxicology, Vol. 41, No. 4, pp. 258-261.

\section{Ref.:}

Radhi, Muhammed Mizher - Al-Dulimy, Wasan A. Gharbi - Khalaf, Maysara Samer: Electrochemical study of Selenium (IV) Mediated by Carbon Nanotubes Modified Glassy Carbon Electrode in blood medium

Építőanyag - Journal of Silicate Based and Composite Materials, Vol. 68, No. 3 (2016), 90-93. p http://dx.doi.org/10.14382/epitoanyag-jsbcm.2016.16

Szén nanocsövekkel módosított üvegszerű szén elektródával közvetített szelén (IV) elektrokémiai vizsgálata vér közegben

Nátrium-szelenit Se(IV) ciklikus voltammetriai vizsgálatát mutatja be a cikk nyál és vér közegben, az oxidatív vagy antioxidatív hatás megfigyeléseirôl. A redox áramerôsség csúcsértékek változását szén nanocsövekkel módosított üvegszerú szén elektródával mérték. Az eredmények szerint Se(IV) redukciós áramerôsség csúcsérték mutatható ki -1V-on a 10 mM nátrium-szelenit koncentráció mellett. Aszkorbinsav adagolása erôsíti a katódos áramerôsség csúcsértékeket és eltünteti az anódos áramerôsség csúcsértékeket. A nátrium-szelenit antioxidatív hatású vér közegben kis koncentráció esetén és oxidatív hatású nagy koncentráció esetén, különösen aszkorbinsav jelenlétében. Kulcsszavak: ciklikus voltmérés, szén nanocsō, üvegszerú szén elektróda, vér, nátrium-szelenit, nyál 